\title{
PENGARUH PERSAINGAN DAN HARGA TERHADAP \\ KEPUTUSAN PEMBELIAN SEPEDA MOTOR PADA CV. GREENTECH BELILAS KABUPATEN INDRAGIRI HULU
}

\author{
HERMANTO \\ Program Studi Manajemen, Sekolah Tinggi Ilmu Ekonomi Indragiri (STIE-I) Rengat \\ Email: hermanto@stieindragiri.ac.id
}

\begin{abstract}
Abstrak
Penelitian ini dilakukan di Desa Pangkalan Kasai Kecamatan Seberida Kabupaten Indragiri Hulu, dengan maksud dan tujuan ingin melihat Pengaruh Persaingan dan Harga Terhadap Keputusan Pembelian Sepeda Motor pada CV. Greentech Belilas Kabupaten Indragiri Hulu. Metode penelitian yang penulis gunakan adalah analisis deskriptis dengan mengunakan data kualitatif yang dikuantitatif dan selanjutnya diolah dengan mengunakan rumus regresi dan kolerasi berganda. Hasil penelitian dari koefesien regresi Pengaruh Persaingan dan Harga Terhadap Keputusan Pembelian Sepeda Motor pada CV. Greentech Belilas Kabupaten Indragiri Hulu maka dapat persamaan $Y=1,953+0,271 X 1+0,511 X 2$, dari persamaan dapat diartikan bahwa jika konstanta sebesar 1,953 artinya jika Persaingan (X1) dan Harga (X2) nilainya adalah 0 maka Keputusan Pembelian nilainya adalah 1,953. Koefesien regresi variabel Persaingan (X2) sebesar 0,271, artinya jika variabel independen lainnya nilainnya tetap dan Persaingan mengalami kenaikan satu satuan maka Keputusan Pembelian akan mengalami kenaikan sebesar 0,271. Sedangkan koefesien Harga (X2) sebesar 0,571 artinya jika variabel independen lainnya tetap dan Harga mengalami kenaikan satu satuan maka Keputusan Pembelian akan mengalami peningkatan sebesar 0,571. Dari hasil penguji $F$ hitung diperoleh nilai $F$ hitung $(24,552)>$ F tabel $(3,11)$ dengan demikian Ha diterma dan Ho ditolak. Untuk pengujian $t$ hitung pada variabel Persaingan didapat nilai $t$ hitung( 2,794) >t tabel (1.99045) Ha diterima dan Ho ditolak artinya adalah terdapat pengaruh signifikan Persaingan terhadap Keputusan Pembelian. Untuk pengujian variabel Harga diperoleh nilai $t$ hitung $(5,664)>t$ tabel (1.99045) Ho ditolak dan Ha diterima artinya terdapat pengaruh signifikan antara Harga terhadap Keputusan Pembelian. Selanjutnya di peroleh $R=0,662$. Artinya hubungan Persaingan dan Harga terhadap Keputusan Pembelian desa mempunyai lemah positif. Selanjutnya dapat dijelaskan bahwa $R 2=0,386$ artinya terdapat kontribusi antara variabel Persaingan dan Harga terhadap Keputusan Pembelian sebesar 38,6\% sedangkan 61,4\% lagi dipengaruhi oleh faktor lain yang tidak diteliti dalam penelitian ini.
\end{abstract}

Kata Kunci : Persaingan, Harga, Keputusan Pembelian. 


\section{PENDAHULUAN}

A. Latar Belakang

Didalam persaingan yang semakin pesat ini, perusahaan harus mampu memenangkan persaingan dengan pesaingnya. Salah satu diantaranya adalah perusahaan kendaraan sepeda motor. Di daerah belilas kecamatan seberida terdapat berbagai macam dealer kendaraan sepeda motor, diantaranya seperti dealer Honda, Yamaha dan Kawasaki. CV. Greentech Belilas Kabupaten Indragiri Hulu merupakan dealer yang menjual kendaraan sepeda motor merek Kawasaki. CV. Greentech Belilas harus mampu bersaing dengan saingannya seperti Honda dan Yamaha.

Persaingan didalam menjual sepeda motor baik dari harganya maupun dari kualitas produk yang dijuga. Berikut penjualan sepeda motor merek Kawasaki pada CV. Greentech Belilas dari tahun 2013 s/d 2017.

Tabel 1. Data Penjualan Unit Sepeda Motor Kawasaki pada CV. Greentech Belilas

Kabupaten Indragiri Hulu tahun 2013 s/d 2017.

\begin{tabular}{|c|c|c|c|}
\hline No & Tahun & Penjualan Sepeda Motor & Persentase (\%) \\
\hline 1. & 2013 & 285 Unit & - \\
\hline 2. & 2014 & 455 Unit & 59,65 \\
\hline 3. & 2015 & 365 Unit & $(19,78)$ \\
\hline 4. & 2016 & 305 Unit & $(16,44)$ \\
\hline 5. & 2017 & 433 Unit & 41,97 \\
\hline
\end{tabular}

Sumber : CV. Greentech Belilas Kabupaten Indragiri Hulu, tahun 2018

Penjualan sepeda motor merek Kawasaki yang mengalami naik turun ini merupakan salah bentuk persaingan bisnis yang dilakukan oleh CV. Greentech Belilas, hal ini bisa dilihat dari produk apa yang dijual, sesuai dengan selera dan trand masa kini. Selain itu persaingan usaha yang dilakukan usaha dilingkungan kerjanya juga mempengaruhi penjualan sepeda motor. Selain persaingan dapat dilihat harga dari produk terjual juga mempengaruhi penjualan sepeda motor merek Kawasaki.

Berikut Harga Produk pada CV. Greentech Belilas Kabupaten Indragiri Hulu tahun 2018 :

Tabel 2. Harga Produk pada CV. Greentech Belilas Kabupaten Indragiri Hulu tahun 2018.

\begin{tabular}{|c|l|ll|}
\hline No. & \multicolumn{1}{|c|}{ Nama Produk } & \multicolumn{2}{c|}{ Harga } \\
\hline 1. & KLX 150 New & Rp. & 31.100 .000 \\
\hline 2. & KLX 150 L BF New & Rp. & 34.700 .000 \\
\hline 3. & KLX 150 BF SE EXTREME & Rp. & 36.900 .000 \\
\hline 4. & NINJA 250L (RR MONO) & Rp. & 47.850 .000 \\
\hline 5. & Z 250 SL BR 250 E & Rp. & 44.950 .000 \\
\hline 6. & NEW D' TRACKER & Rp. & 34.200 .000 \\
\hline 7. & NEW D' TRACKER SE & Rp. & 35.600 .000 \\
\hline 8. & NINJA 250 ABS (EX 250 M) & Rp. & 76.000 .000 \\
\hline 9. & NINJA 250 EX 250 L & Rp. & 64.100 .000 \\
\hline 10. & NINJA 250 LTD & Rp. & 67.500 .000 \\
\hline 11. & Z 125 PRO BR 125 H & Rp. & 34.300 .000 \\
\hline
\end{tabular}

Sumber : CV. Greentech Belilas Kabupaten Indragiri Hulu tahun 2018

Produk yang dijual kendaraan sepeda motor merek Kawasaki ini relatife tinggi harganya, hal ini membuat konsumen berat dalam memiliki produk tersebut. Berbeda 
dengan perusahaan lain seperti hoda dan Yamaha menawarkan produk dengan harga yang rendah dengan produk yang berbeda pula.

Berdasarkan uraian latar belakang diatas maka penelitian ini mengambil judul "PENGARUH PERSAINGAN DAN HARGA TERHADAP KEPUTUSAN PEMBELIAN SEPEDA MOTOR PADA CV. GREENTECH BELILAS KABUPATEN INDRAGIRI HULU"

\section{B. RUMUSAN MASALAH}

1) Apakah Persaingan dan Harga secara simultan berpengaruh terhadap Keputusan Pembelian Sepeda Motor pada CV. Greentech Belilas Kabupaten Indragiri Hulu.

2) Apakah Persaingan secara parsial berpengaruh terhadap Keputusan Pembelian Sepeda Motor pada CV. Greentech Belilas Kabupaten Indragiri Hulu.

3) Apakah Harga secara parsial berpengaruh terhadap Keputusan Pembelian Sepeda Motor pada CV. Greentech Belilas Kabupaten Indragiri Hulu.

\section{Tujuan Penelitian}

1) Untuk mengetahui pengaruh Persaingan dan Harga secara simultan berpengaruh terhadap Keputusan Pembelian Sepeda Motor pada CV. Greentech Belilas Kabupaten Indragiri Hulu.

2) Untuk mengetahui pengaruh Persaingan secara parsial berpengaruh terhadap Keputusan Pembelian Sepeda Motor pada CV. Greentech Belilas Kabupaten Indragiri Hulu.

3) Untuk mengetahui pengaruh Harga secara parsial berpengaruh terhadap Keputusan Pembelian Sepeda Motor pada CV. Greentech Belilas Kabupaten Indragiri Hulu.

\section{TINJAUAN PUSTAKA}

Kotler, (2011:206), mengungkapkan keputusan untuk membeli yang diambil oleh konsumen itu merupakan kumpulan dari sejumlah keputusan. Setiap keputusan membeli mempunyai suatu struktur yang terdiri dari beberapa komponen, antara lain. 1) Keputusan tentang jenis produk, 2) Keputusan tentang bentuk produk, 3) Keputusan tentang merek, merek mana yang akan dipilih konsumen untuk dibeli, 4) Keputusan tentang penjualnya, produk tersebut dibeli dimana dan pada toko apa, 5) Keputusan tentang jumlah produk, banyaknya produk yang akan dibeli, 6) Keputusan tentang waktu pembelian. 7) Keputusan tentang cara pembayaran.

Selanjutnya menurut Kotler, (2011:206) mengungkapkan bahwa terdapat dua faktor yang pada akhirnya mempengaruhi keputusan pembelian, pertama, sikap orang lain. Sejauh mana sikap orang lain mengurangi alternatif yang disukai seseorang, pengurangan alternatif tersebut akan bergantung kepada dua hal yaitu; 1) Intensitas sikap negatif orang lain terhadap alternatif yang disukai konsumen. 2) Motivasi konsumen untuk menuruti keinginan orang lain. Semaking gencar sikap negatif orang lain akan semakin besar pula konsumen akan mengubah niat pembeliannya. Sebaiknya preferensi seorang pembeli terhadap suatu merek akan meningkat jika seseorang yang ia sukai juga sangat menyukai merek yang sama. Kedua, Situasi yang tidak terantisipasi. Situasi yang tidak terantisipasi yang dapat muncul dan mengubah niat pembelian, keputusan konsumen untuk memodifikasi, menunda atau menghindari suatu keputusan pembelian sangat dipengaruhi oleh resiko yang dirasakan. Bersama resiko yang dirasakan berbeda-beda menurut besarnya uang yang dipertaruhkan besarnya ketidak pastian atribut dan besarnya kepercayaan diri konsumen. Untuk mengurangi resiko-resiko itu, maka konsumen 
mengembangkan rutinitas tertentu seperti penghindaran keputusan, pengumpulan informasi dari teman-teman dan preferensi atas merek dalam negeri dan garansi.

Sementara itu menurut Tjiptono (2010:135) diungkapkan bahwa seseorang Konsumen membeli suatu Produk itu dipengaruhi oleh dua dimensi, 1) Dimensi rasional. Seperti harga, kualitas, distribusi dan sebagainya yang dapat mendorong seseorang untuk membeli suatu product dengan alasan-alasan yang rasional. 2) Dimensi daya tarik. Seperti aroma produk, warna, bentruk, rasa dan sebagainya.

Persaingan berasal dari bahasa Inggris yaitu competition yang artinya persaingan itu sendiri atau kegiatan bersaing, pertandingan, kompetisi. sedangkan dalam kamus manajemen, persaingan adalah usaha-usaha dari 2 pihak/lebih perusahaan yang masingmasing bergiat ,memperoleh pesanan ' dengan menawarkan harga/syarat yang paling menguntungkan. Persaingan ini dapat terdiri dari beberapa bentuk pemotongan harga, iklan/promosi, variasi dan kualitas, kemasan, desain, dan segmentasi pasar. (Maribun, 2003:276)

Persaingan merupakan kondisi real yang dihadapi setiap orang di masa sekarang. Kompetisi dan persaingan tersebut bila dihadapi secara positif atau negatif, bergantung pada sikap dan mental persepsi kita dalam memaknai persaingan tersebut. Hampir tiada hal yang tanpa kompetisi/persaingan, seperti halnya kompetisi dalam berprestasi, dunia usaha bahkan dalam proses belajar. Persaingan merupakan semacam upaya untuk mendukuki posisi yang lebih tinggi di dalam dunia usaha. Bila jumlah pesaing cukup banyak dan seimbang, persaingan akan tinggi sekali karena masing-masing perusahaan memiliki sumber daya yang relatif sama. Bila jumlah pesaing sama tetapi terdapat perbedaan sumber daya, maka terlihat sekali mana yang akan menjadi market leader, dan perusahaan mana yang merupakan pengikut. (Jusuf, 2008:206)

Penerapan harga bertujuan untuk mencapai memperoleh keuntungan, penetapan harga sangatlah berpengaruh pada penetapan posisi produknya yang berdasarkan kualitas. Menurut Basu swastha (2003:241) "Harga merupakan sejumlah uang yang harus dibayar oleh konsumen atau pembeli untuk mendapatkan produk yang ditawarkan oleh penjual. Penetapan harga jual harus disesuaikan dengan daya beli konsumen yang dituju dan dengan mempertimbangkan faktor biaya, laba, pesaing, dan perubahan keinginan pasar. Menurut Fandy Tjiptono (2008:151) menyebutkan bahwa harga merupakan satu - satunya unsur bauran pemasaran yang memberikan pemasukan atau pendapatan bagi perusahaan. Menurut Kotler dan Keller yang dialih bahasakan oleh Bob Sabran (2009:67), harga adalah salah satu elemen bauran pemasaran yang menghasilkan pendapatan, elemen lain menghasilkan biaya. Harga merupakan elemen termudah dalam program pemasaran untuk disesuaikan, fitur produk, saluran, dan bahkan komunikasi membutuhkan banyak waktu. Menurut Swastha ( 2010 : 147 ), “ Harga adalah jumlah uang (ditambah beberapa barang kalau mungkin ) yang dibutuhkan untuk mendapatkan sejumlah kombinasi dari barang beserta pelayanannya ".

\section{METODE PENELITIAN}

A. Lokasi Penelitian

Lokasi penelitian yang dijadikan objek penelitian ini adalah Desa Pangkalan Kasai Kecamatan Seberida Kabupaten Indragiri Hulu.

B. Jenis dan Sumber Data

Data primer adalah data yang diperoleh langsung dari lapangan yang berasal dari konsumen kawasaki langsung dan pimpinan perusahaan, dan Data sekunder adalah data yang diperoleh melalui pihak lain diluar responden, yang sudah ada. 
C. Teknik Pengumpulan Data

1. Interview adalah dengan mengadakan wawancara secara langsung terhadap Konsumen Kawasaki dan Pimpinan Perusahaan, tentang berbagai hal yang erat hubunganya dengan masalah yang dibahas.

2. Questioner adalah dengan mengunakan daftar pertanyaan yang diajukan kepada Konsumen Kawasaki di Kecamatan Seberida guna memperoleh data yang lebih jelas mengenai keadaan yang berhubungan dengan masalah penelitian.

D. Populasi dan Sampel

Adapun populasi yang penulis jadikan dalam objek penelitian ini adalah konsumen yang membeli sepeda motor Kawasaki pada CV. Greentech Belilas Kabupaten Indragiri Hulu berjumlah 433 orang. Teknik pengambilan sampel dengan cara purposive sampling yaitu karena pengambilan anggota sampel dari populasi dilakukan secara acak tanpa memperhatikan strata yang ada dalam populasi tersebut.

Untuk menentukan ukuran sampel dari populasi, ada beberapa macam cara yang dikemukakan para ahli, antara lain seperti yang dijelaskan sebagai berikut, Adapun rumus ukuran sampel menurut pendapat Slovin sebagai berikut : (Umar, 2005:146)

$$
n=\frac{N}{1+N e^{2}}
$$

Dimana :

$\mathrm{n}=$ jumlah sampel

$\mathrm{N}=$ jumlah populasi

$\mathrm{e}=$ batas toleransi kesalahan

$=\frac{433}{1+433(10 \%)^{2}}$

$=\frac{433}{1+1433(0,01)}$

$=\frac{433}{1+4,33}$

$=\frac{433}{5,33}$

$=81,24$ (dibulatkan menjadi 81)

Jadi, sampel yang penulis ambil dalam penelitian ini adalah sebanyak 81 responden.

E. Analisis Data

Analisis data yang digunakan penulis yaitu metode kuantitatif dengan analisis regresi linier berganda, karena variabel yang diteliti hanya terdiri dari tiga variabel ( dua variabel bebas dan satu variabel terikat), untuk memudahkan penulis dalam melakukan analisis data penulis menggunakan program SPSS Versi 21.

1. Analisis Regresi Linier Berganda

Adapun persamaan linier regresi berganda adalah sebagai berikut :

$\mathrm{Y}=\mathrm{a}+\mathrm{b} 1 \mathrm{X} 1+\mathrm{b} 2 \mathrm{Y} 2+\mathrm{e}$

Keterangan :

$\mathrm{Y}=$ Keputusan Pembelian

$\mathrm{a}=$ Konstanta

$\mathrm{b} 1-\mathrm{b} 2=$ Koefesien regresi

$\mathrm{X} 1=$ Persaingan 
$\mathrm{X} 2=$ Harga

$\mathrm{e} \quad=$ Variabel penggangu

2. Pengajuan hipotesi dengan cara :

a. Uji F ( Uji simultan )

Untuk menentukan nilai $\mathrm{F}$ tabel, tingkat sinifikan yang digunakan sebesar $10 \%$ dengan derajat kebebasan (degree of feedom) $\mathrm{df}=(\mathrm{n}-\mathrm{k})$ dimana (n) adalah jumlah observasi dan $(\mathrm{k})$ adalah jumlah variabel. Kriteria uji yang digunakan adalah sebagai berikut :

- Jika F hitung < F tabel (k-1)(n-k) maka hipotesis nol Ho diterima, artinya secara statistik dapat dibutikan bahwa semua variabel X1 dan $\mathrm{X} 2$ telah berpengaruh terhadap perubahan variabel (Y).

- Jika F hitung > F tabel (k-1)(n-k) maka hipotesis nol Ho ditolak dan hipotesis alternatif Ha diterima, artinya secara simultan dapat dibutikan bahwa semua variabel $\mathrm{X} 1$ dan $\mathrm{X} 2$ telah berpengaruh terhadap perubahan nilai variabel sisa $(Y)$.

b. Uji t (uji parsial)

Keandalan analisis linier berganda sebagai alat estimasi dengan ditentukan oleh sinifikan parameter-parameter yang dalam hal ini adalah koefisien regresi. Uji t digunakan untuk menguji koefisien regresi secara parsial dan variabel independen nya, untuk menentukan nilai t ststistik tabel digunakan tingkat sinifikan 5\% dengan drajat kebebasan $\mathrm{df}=(\mathrm{n}-\mathrm{k}-1)$ dimana $(\mathrm{n})$ adalah jumlah observasi dan (k) adalah jumlah variabel. Kriteria uji yang digunakan adalah sebagai berikut :

- Jika t hitung< t tabel, maka hipotesis nol Ho diterima, artinya variabel $\mathrm{X} 1$ dan $\mathrm{X} 2$ secara parsial tidak berpengaruh terhadap perubahan nilai variabel sisa $(\mathrm{Y})$

- Jika t hitung> t tabel, maka hipotesis nol Ho ditolak, dan hipotesis alternatif $\mathrm{Ha}$ diterima, artinya variabel $\mathrm{X} 1$ dan $\mathrm{X} 2$ secara parsial berpengaruh terhadap perubahan nilai variabel $(\mathrm{Y})$.

3. Koefisien Korelasi (R) dan Determinasi (R2).

Koefisien korelasi adalah nilai yang menunjukan kekuatan dan arah hubungan linier antara dua perubahan acak (random variabel).

\section{PEMBAHASAN}

1. Identitas Responden

Responden yang digunakan dalam penelitian ini adalah konsumen yang membeli kendaraan sepeda motor Kawasaki di wilayah lingkungan kerja CV. Greentech Belilas Kabupaten Indragiri Hulu.

2. Variabel Persaingan

Adapun hasil rekapitulasi hasil penyebaran quisioner variabel persaingan sebagai berikut :

Tabel 3. Rekapitulasi hasil quisioner variabel persaingan

\begin{tabular}{|l|c|c|c|c|c|c|c|}
\hline \multirow{2}{*}{ Indikator } & \multicolumn{6}{|c|}{ Alternatif Jawaban } & Jumlah \\
\cline { 2 - 9 } & SB & B & CB & KB & TB & & \\
\hline Lingkungan usaha & 16 & 44 & 21 & & & 319 & 3,94 \\
\hline Perekonomian daerah & 24 & 40 & 17 & & & 331 & 4,09 \\
\hline $\begin{array}{l}\text { Ketenagakerjaan dan sumberdaya } \\
\text { manusia }\end{array}$ & 42 & 30 & 9 & & & 357 & 4,41 \\
\hline Infrastruktur, sumberdaya alam dan & 27 & 41 & 13 & & & 338 & 4,17 \\
\hline
\end{tabular}




\begin{tabular}{|l|c|c|c|c|c|c|c|}
\hline lingkungan & & & & & & & \\
\hline Perbankan dan lembaga keuangan & 7 & 53 & 21 & & & 310 & 3,83 \\
\hline Sekor Jawaban & 5 & 4 & 3 & 2 & 1 & 1.655 & 20,44 \\
\hline
\end{tabular}

Sumber Data : dari hasil penyebaran quisioner variabel X1

Dari tabel diatas, dapat dilihat bahwa untuk variabel Persaingan (X1) tergolong ke kriteria "baik" dengan nilai 4,09 yaitu menunjukan nilai bobot 4 .

3. Variabel Harga

Adapun hasil rekapitulasi hasil penyebaran quisioner variabel Harga sebagai berikut :

Tabel 4. Rekapitulasi hasil quisioner variabel Harga

\begin{tabular}{|l|c|c|c|c|c|c|c|}
\hline \multirow{2}{*}{ Indikator } & \multicolumn{6}{|c|}{ Alternatif Jawaban } & Jumlah \\
\cline { 2 - 8 } & SB & B & CB & KB & TB & & \\
\hline Keterjangkauan harga & 33 & 33 & 15 & & & 342 & 4,22 \\
\hline $\begin{array}{l}\text { Kesesuaian harga dengan kualitas } \\
\text { produk }\end{array}$ & 27 & 37 & 17 & & & 334 & 4,12 \\
\hline Daya saing harga & 27 & 34 & 20 & & & 331 & 4,09 \\
\hline Kesesuaian harga dengan manfaat & 29 & 40 & 12 & & & 341 & 4,21 \\
\hline Sekor Jawaban & 5 & 4 & 3 & 2 & 1 & 1.348 & 16,64 \\
\hline
\end{tabular}

Sumber Data : dari hasil penyebaran quisioner variabel X2

Dari tabel diatas, dapat dilihat bahwa untuk variabel Harga (X2) tergolong ke kriteria "baik" dengan nilai 4,16 yaitu menunjukan nilai bobot 4 .

4. Variabel Keputusan Pembelian

Adapun hasil rekapitulasi hasil penyebaran quisioner variabel Keputusan Pembelian sebagai berikut :

Tabel 5. Rekapitulasi hasil quisioner variabel Keputusan Pembelian

\begin{tabular}{|c|c|c|c|c|c|c|c|}
\hline \multirow[t]{2}{*}{ Indikator } & \multicolumn{5}{|c|}{ Alternatif Jawaban } & \multicolumn{2}{|c|}{\begin{tabular}{l|l} 
Jumlah A \\
\end{tabular}} \\
\hline & SB & B & $\mathrm{CB}$ & KB & TB & & \\
\hline Kemantapan pada sebuah produk & 19 & 37 & 25 & & & 318 & 3,93 \\
\hline Kebiasaan dalam membeli produk & 23 & 35 & 23 & & & 324 & 4,00 \\
\hline $\begin{array}{l}\text { Menberikan rekomendasi kepada } \\
\text { orang lain }\end{array}$ & 27 & 38 & 16 & & & 335 & 4,14 \\
\hline Melakukan pembelian ulang & 16 & 44 & 21 & & & 319 & 3,94 \\
\hline Sekor Jawaban & 5 & 4 & 3 & 2 & 1 & 1.296 & 16,01 \\
\hline
\end{tabular}

Sumber Data : dari hasil penyebaran quisioner variabel X2

Dari tabel diatas, dapat dilihat bahwa untuk variabel Keputusan Pembelian (Y) tergolong ke kriteria "baik" dengan nilai 4, yaitu menunjukan nilai bobot 4 . 
5. Regresi Linear Berganda

Berikut hasil penelitan dengan melihat regresi linear berganda sebagai berikut :

Tabel 6. Untuk melihat Pengaruh Persaingan dan Harga terhadap Keputusan Pembelian Sepeda Motor pada CV. Greentech Belilas Kabupaten Indragiri Hulu

\begin{tabular}{|c|c|c|c|c|c|c|}
\hline \multicolumn{7}{|c|}{ Coefficients $^{a}$} \\
\hline \multirow{2}{*}{\multicolumn{2}{|c|}{ Model }} & \multicolumn{2}{|c|}{ Unstandardized Coefficients } & \multirow{2}{*}{$\begin{array}{c}\text { Standardized } \\
\text { Coefficients } \\
\text { Beta }\end{array}$} & \multirow[t]{2}{*}{$\mathrm{t}$} & \multirow[t]{2}{*}{ Sig. } \\
\hline & & $\mathrm{B}$ & Std. Error & & & \\
\hline \multirow{3}{*}{1} & (Constant) & 1.953 & 2.219 & & .880 & .382 \\
\hline & Persaingan & .271 & .097 & .254 & 2.794 & .007 \\
\hline & Harga & .511 & .090 & .515 & 5.664 & .000 \\
\hline
\end{tabular}

a. Dependent Variable: Keputusan Pembelian

Dari hasil perhitungan koefesien regresi, Pengaruh Persaingan dan Harga terhadap Keputusan Pembelian Sepeda Motor pada CV. Greentech Belilas Kabupaten Indragiri Hulu, dapat ditampilkan kedalam bentuk persamaan regresi berganda sebagai berikut:

$\mathrm{Y}=\mathrm{a}+\mathrm{b} 1 \mathrm{X} 1+\mathrm{b} 2 \mathrm{X} 2$.

Dari persamaan diatas diperoleh dari hasil perhitungan regresi sebagai berikut :

$\mathrm{Y}=1,953+0,271 \mathrm{X} 1+0,511 \mathrm{X} 2$.

Dari persamaan diatas dapat diartikan bahwa :

a. Konstanta sebesar 1,953 artinya jika Persaingan (X1) dan Harga (X2) nilainya 0 maka Keputusan Pembelian nilainya adalah 1,953.

b. Koefesien regresi variabel Persaingan (X1) sebesar 0,271, artinya jika variabel independen lainnya nilainnya tetap Persaingan mengalami kenaikan satu satuan maka Keputusan Pembelian akan mengalami peningkatan sebesar 0,271.

c. Sedangkan koefesien regresi Harga (X2) sebesar 0,511 artinya jika variabel independen lainnya tetap dan Harga mengalami kenaikan satu satuan maka Keputusan Pembelian akan mengalami naik sebesar 0,511.

6. Uji F

Untuk melihat pengaruh variabel bebas secara silmutan terhadap variabel terikat yaitu hubungan Persaingan (X1) dan Harha (X2) terhadap Keputusan Pembelian (Y) menggunakan uji $\mathrm{F}$ sebagai berikut :

Tabel 7. Hasil Uji F

ANOVA $^{\mathrm{a}}$

\begin{tabular}{|c|c|c|c|c|c|c|}
\hline \multicolumn{2}{|c|}{ Model } & Sum of Squares & $\mathrm{df}$ & Mean Square & $\mathrm{F}$ & Sig. \\
\hline \multirow{3}{*}{1} & Regression & 125.170 & 2 & 62.585 & 24.552 & $.000^{\mathrm{b}}$ \\
\hline & Residual & 198.830 & 78 & 2.549 & & \\
\hline & Total & 324.000 & 80 & & & \\
\hline
\end{tabular}

a. Dependent Variable: Keputusan Pembelian

b. Predictors: (Constant), Harga, Persaingan 
Dengan menggunakan tingkat keyakinan 97\%, $a=3 \%$ df 1 (jumlah variabel -1$)=$ 2 dan df $2(n-k-1)$ atau 81-2-1= 78 maka diperoleh $F$ tabel sebesar 3,11.

Dari tabel diatas dapat diperoleh bahwa nilai F hitung 23,297. Dengan kriteria pengujian :

a. Jika F hitung < F Tabel maka Ho diterima dan Ha ditolak Artinya Ho ; b1 ; b2 = 0 , artinya variabel Persaingan dan Harga tidak berpengaruh terhadap Keputusan Pembelian.

b. Jika F hitung > F tabel maka Ho ditolak dan Ha diterima. Artinya Ha ; b1 ; b2 ; 0 , artinya variabel Persaingan dan Harga berpengaruh terhadap Keputusan Pembelian.

Maka dari hasil pengujian diatas, maka penulis dapat memberikan kesimpulan bahwa F hitung $(24,552)>\mathrm{F}$ tabel $(3,11)$ dengan demikian Ha diterima Ho ditolak, artinya variabel Persaingan dan Harga berpengaruh signifikan terhadap Keputusan Pembelian.

7. Uji t

Perbandingan $\mathrm{t}$ hitung maka dicari $\mathrm{t}$ (tabel) dengan ketentuan derajat kebebasan sebesar $\mathrm{n}-\mathrm{k}$, sedangkan tingkat kepercayaan pada $\mathrm{a}=0,05$ untuk pengujian, Perhitunganya sebagai berikut :

Tabel $=\mathrm{a} / 2: \mathrm{n}-2$

$0,05 / 2: 81-2=1,99045$.

Diperoleh $\mathrm{t}$ tabel 1,99045 .

Maka ditarik kesimpulan sebagai berikut :

a. Didapat $t$ hitung variabel Persaingan $(2,794)>t$ tabel $(1,99045)$ Ha diterima dan Ho ditolak artinya adalah terdapat pengaruh signifikan antara Persaingan dengan Keputusan Pembelian.

b. Didapat t hitung variabel Harga $(5,664)>t$ tabel $(1,99045)$ Ha diterima dan Ho ditolak artinya adalah terdapat pengaruh signifikan antara Harga dengan Keputusan Pembelian.

8. Koefesien Korelasi (R) dan Determinasi (R2)

Dibawah ini adalah hasil tabel Koefesien Korelasi (R) dan Determinasi (R2) :

Tabel 8. Mengukur Peengaruh dan Persentase Kontribusi Variabel bebas terhadap variabel terikat.

Model Summary

\begin{tabular}{|l|r|r|r|c|}
\hline Model & \multicolumn{1}{|c|}{$\mathrm{R}$} & $\mathrm{R}$ Square & \multicolumn{1}{|c|}{$\begin{array}{l}\text { Adjusted } \mathrm{R} \\
\text { Square }\end{array}$} & $\begin{array}{l}\text { Std. Error of the } \\
\text { Estimate }\end{array}$ \\
\hline 1 & $.622^{\mathrm{a}}$ & .386 & .371 & 1.59659 \\
\hline
\end{tabular}

a. Predictors: (Constant), Harga, Persaingan

Selanjutnya untuk mengetahui seberapa besar hubungan Pengaruh Persaingan dan Harga Terhadap Keputusan Pembelian Sepeda Motor pada CV. Greentech Belilas Kabupaten Indragiri Hulu yaitu $\mathrm{R}=0,622$, artinya hubungan Persaingan dan Harga terhadap Keputusan Pembelian mempunyai hubungan sedang dan positif. Selanjutnya dapat dijelaskan bahwa $\mathrm{R} 2=0,386$ artinya terdapat kontribusi antara variabel Persaingan dan Harga terhadap Keputusan Pembelian sebesar 38,6\% sedangkan 61, 4\% lagi dipergunakan oleh faktor lain yang tidak diteliti dalam penelitian ini. 


\section{PENUTUP}

\section{A. Kesimpulan}

Kesimpulan yang dapat diambil dari penelitian ini adalah bahwa secara simultan dan parsial variabel Persaingan dan Harga berpengaruh secara signifikan terhadap Keputusan Pembelian Sepeda Motor pada CV. Greentech Belilas Kabupaten Indragiri Hulu. Variabel harga memiliki pengaruh dominan terhadap Keputusan pembelian dibandingkan variabel harga.

B. Saran

Dari kesimpulan tersebut diatas, maka dapat penulis memberikan saran sebagai berikut :

1. Perusahaan sebaiknya menghindari persaingan yang dapat merugikan dengan menentukan target dan sasaran pada pasar.

2. Harga yang ditawarkan untuk kendaraan perlu diperhatikan, agar masyarakat terjangkau membeli kendaraan sepeda motor seperti pesaing Honda dan Yamaha.

3. Keputusan Pembelian Konsumen perlu diperhatikan khusus, karena apa keinginan dan kebutuhan tentang produk yang akan dijual menjadi prioritas perusahaan dalam memproduksi produk.

\section{DAFTAR PUSTAKA}

Basu, Swastha dan Irawan, 2003, Manajemen Pemasaran Modern, Liberty, Yogyakarta.

Basu, Swasta dan Handoko, Hani, 2010, Manajemen Pemasaran: Analisa dan. Perilaku Konsumen, BPFE, Yogyakarta.

Husein Umar, 2005, Metode Penelitian Untuk Skripsi dan Tesis Bisnis, PT. Raja Grafindo Persada, Jakarta.

Jusuf, Jopie, 2008, Analisis Kredit untuk Account Officer, PT. Gramedia Pustaka Utama, Jakarta.

Kotler, Philip dan Keller, Kevin Lane, 2009, Manajemen Pemasaran. Edisi Ketigabelas. Jilid 1. Alih bahasa Bob Sabran, Penerbit Erlangga, Jakarta.

Kotler. P, 2011, Manajemen Pemasaran. Jilid 2, Bumi Aksara, Jakarta.

Maribun, B. N, 2003, Kamus Manajemen, Pustaka Sinar Harapan, Jakarta.

Tjiptono, Fandy, 2008, Strategi Pemasaran, Edisi 3, ANDI, Yogyakarta.

Tjiptono, Fandy, 2010, Manajamen Pemasaran Edisi III, Penerbit Andi Offset, Yogyakarta. 